Lesser Sunda

P-ISSN: 2775-0078

Januari 2021

E-ISSN: 2775-0086

Vol. 1(2):9-14

\title{
Diversitas Plankton di Perairan Pantai Sire Kabupaten Lombok Utara
}

\author{
Baiq Hilda Astriana ${ }^{* 1}$, Chandrika Eka Larasati ${ }^{1}$ \\ ${ }^{1}$ Program Studi Ilmu Kelautan, Jurusan Perikanan dan Ilmu Kelautan, \\ Fakultas Pertanian, Universitas Mataram \\ *arda804@yahoo.co.id
}

Naskah diterima : 20 November 2020, Disetujui : 9 Januari 2021

\begin{abstract}
Plankton has an important role for aquatic ecosystems, especially in the food network in a waters. This study aims to assess the abundance and diversity index of plankton in Sire Beach, North Lombok Regency. The study was conducted in September 2019 using purposive sampling with 9 sample points. The water sample was filtered using plankton net then put into the sample bottle for identification in the laboratory. Shannon-Wienner Index was used for determining diversity of plankton species. The types of plankton found were 12 genera of phytoplankton from the Bacillariophyta group, including: Biddulphia, Coscinodiscus, Cocconeis, Cylindrotheca, Diploneis, Fragilaria, Gyrosigma, Licmophora, Navicula, Nitzschia, Pleurosigma, and Triceratium. The highest abundance of phytoplankton belonged to Coscinodiscus species as many as 1.380 cells/l at station 2.3. The high abundance of Coscinodiscus might be due to a nutrient supply in these waters. Seagrass ecosystem was thought to have an important role in obtaining nutrients for phytoplankton. Diversity index has a value which ranges between 1.1175051.841236 showing that it is in the medium category. The uniformity index ranges from 0.450718-0.673373 indicating that the distribution of plankton species in each station is even. The dominance index ranges from 0.233508-0.522215. This shows that there is no type of plankton that dominates the waters of Sire Beach. This is due to the abundance of plankton species at each station which is fairly evenly distributed.
\end{abstract}

Keywords: Diversity, sire beach, plankton

\section{PENDAHULUAN}

Plankton diartikan sebagai organisme renik yang hanyut di perairan laut yang memiliki keterbatasan gerak, sehingga mudah dibawa oleh arus (Hartoko, 2013; Lovadi et al., 2015). Berdasarkan fungsinya, plankton terbagi atas fitoplankton dan zooplankton. Fitoplankton memiliki peranan penting sebagai produsen primer dalam rantai makanan pada ekosistem perairan, sedangkan zooplankton menduduki posisi konsumer pertama dalam ekosistem perairan yang mana berperan dalam memakan fitoplankton, selanjutnya zooplankton dimakan oleh organisme tingkat tinggi seperti ikan (Nontji, 2007).

Pulau Lombok merupakan salah satu pulau di Provinsi Nusa Tenggara Barat yang memiliki garis pantai yang relatif panjang yaitu $423 \mathrm{~km}$. Salah satu kabupaten yang termasuk dalam provinsi ini adalah Kabupaten Lombok Utara dengan panjang pantai dan teluk $67,52 \mathrm{~km}$. (Direktorat 
Kepolisian Perairan NTB, 2017). Potensi laut yang dimiliki wilayah ini telah mendorong kegiatan pemanfaatan sumberdaya laut di kawasan ini yang tidak hanya difokuskan pada perikanan tangkap, tetapi juga kegiatan budidaya dan ekowisata. Salah satu kawasan perairan laut yang termasuk ke dalam wilayah kabupaten ini adalah Pantai Sire yang terletak di Desa Medana, Kecamatan Tanjung. Pantai Sire telah lama menjadi salah satu destinasi wisata di kabupaten ini. Selain itu, di kawasan perairan ini banyak ditemukan biota-biota laut yang menarik untuk diambil oleh para wisatawan. Beberapa tahun belakangan telah terjadi degradasi kualitas lingkungan yang ditunjukkan dengan semakin berkurangnya biota-biota menarik tersebut dan pencemaran yang diakibatkan oleh akumulasi limbah yang dihasilkan dari kegiatan wisata.

Setiap aktivitas antropogenik yang dilakukan di kawasan pesisir pada dasarnya dapat berpengaruh pada diversitas jenis plankton di Pantai Sire. Mengingat peranan plankton sebagai bioindikator lingkungan perairan dan pentingnya mengetahui perubahan kualitas lingkungan perairan terutama di kawasan perairan laut Pantai Sire, Kabupaten Lombok Utara, maka perlu dikaji diversitas jenis plankton di wilayah tersebut.

\section{METODE PENELITIAN}

Penelitian ini dilaksanakan pada bulan September 2019 di perairan Pantai Sire, Desa Sigar Penjalin, Kabupaten Lombok Utara (Gambar 1). Titik sampling terbagi atas 9 stasiun secara purposive sampling yang dianggap telah mewakili kawasan pantai Sire. Identifikasi jenis plankton dilakukan di Laboratorium
Bioekologi Program Studi Budidaya Perairan Universitas Mataram.

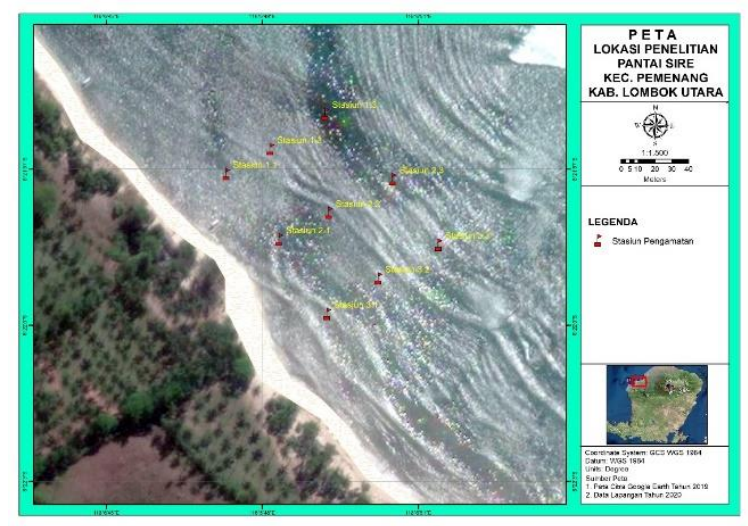

Gambar 1 Peta Lokasi penelitian

Berdasarkan standard method (APHA, 2005), pengambilan sampel plankton dilakukan dengan menyaring sampel air laut menggunakan plankton net dengan mesh size $20 \mu \mathrm{m}$ sebanyak $50 \mathrm{ml}$. Pengambilan sampel dilakukan sebanyak 2 kali ulangan. Setelah disaring, sampel diberi larutan Lugol sebanyak 4 tetes untuk diawetkan. Pengamatan jenis plankton dilakukan di laboratorium menggunakan mikroskop binokuler perbesaran 100X yang mengacu pada buku identifikasi Lebour (1930), Allen dan Cupp (1935), dan Davis (1955). Kelimpahan jenis plankton dihitung dengan menggunakan Sedgwick Rafter Cell. Diversitas jenis plankton dapat digunakan indeks Shannon-Wienner (Odum, 1993).

\section{HASIL DAN PEMBAHASAN}

\section{Distribusi dan Komposisi}

Hasil pengamatan menunjukkan bahwa di sekitar Pantai Sire, Kabupaten Lombok Utara teridentifikasi 12 genera fitoplankton yang berasal dari kelas Bacillariophyta, diantaranya yaitu: Biddulphia, Coscinodiscus, Cocconeis, Cylindrotheca, Diploneis, Fragilaria, 
Gyrosigma, Licmophora, Navicula, Nitzschia, Pleurosigma, dan Triceratium (Tabel 1). Selain itu, fitoplankton khususnya diatom banyak ditemukan di seluruh perairan, baik perairan tawar maupun laut (Nogueira, 2000; Yerli et al., 2012).

Kelimpahan jenis plankton banyak ditemukan pada jenis Coscinodiscus memiliki kelimpahan tertinggi di seluruh stasiun pengamatan. Dimana kelimpahan Coscinodiscus tertinggi berada pada Stasiun 2.3 (1.380 sel/l), diikuti dengan Stasiun 2.1 (1.379 sel/l) (Gambar 2). Tingginya kelimpahan jenis Coscinodiscus diduga karena adanya suplai nutrient yang berada di perairan tersebut. Ekosistem padang lamun diduga memiliki peranan penting dalam mendapatkan nutrien bagi fitoplankton (Risamasu dan Prayitno, 2011). Detritus daun lamun yang tua (serasah) didekomposisikan oleh jasad bentik seperti bakteri, teripang, kerang dan kepiting, sehingga menghasilkan suatu bahan organik (baik yang tersuspensi maupun yang terlarut) dalam bentuk nutrien. Nutrien tersebut selain dimanfaatkan oleh tumbuhan lamun itu sendiri, juga dimanfaatkan dalam pertumbuhan fitoplankton (Dahuri, 2003). Selain itu, jenis Coscinodiscus umumnya banyak ditemukan di perairan tropis dan mampu beradaptasi dengan salinitas yang berbeda (euryhaline), sehingga jenis tersebut melimpah di berbagai perairan (Mukherjee et al., 2013; Larasati et al., 2015).

Tabel 1 Jenis Plankton yang Ditemukan Selama Penelitian

\begin{tabular}{llccccccccc}
\hline \multirow{2}{*}{ No } & \multicolumn{1}{c}{ Genera } & \multicolumn{10}{c}{ Stasiun } \\
\cline { 3 - 10 } & & 1.1 & 1.2 & 1.3 & 2.1 & 2.2 & 2.3 & 3.1 & 3.2 & 3.3 \\
\hline 1 & Biddulphia & + & + & + & + & + & + & + & + & + \\
2 & Coscinodiscus & + & + & + & + & + & + & + & + & + \\
3 & Cocconeis & + & + & + & + & + & + & + & + & + \\
4 & Cylindrotheca & + & + & + & + & + & + & - & + & - \\
5 & Diploneis & + & + & + & + & + & + & + & - & - \\
6 & Fragillaria & + & + & + & + & + & + & + & + & + \\
7 & Gyrosigma & + & + & + & + & + & + & + & + & + \\
8 & Licmophora & + & + & + & + & + & + & + & + & + \\
9 & Navicula & + & + & + & + & + & + & + & + & + \\
10 & Nitzschia & + & + & + & + & + & + & + & + & + \\
11 & Pleurosigma & + & + & + & + & + & + & + & + & + \\
12 & Triceratium & + & - & - & - & - & - & - & - & - \\
\hline
\end{tabular}

Keterangan: $+=$ ditemukan jenis plankton - = tidak ditemukan jenis plankton

Sebaran kelimpahan plankton menunjukkan tingginya kelimpahan plankton pada Stasiun 2.1 dan 2.3 (Gambar 2). Selain itu, penyebaran plankton terlihat cukup merata. Hal ini disebabkan oleh adanya proses fisik, kimia dan biologi perairan pantai, sehingga akan berdampak pada sebaran kelimpahan jenis plankton (Adinugroho et al., 2014). 


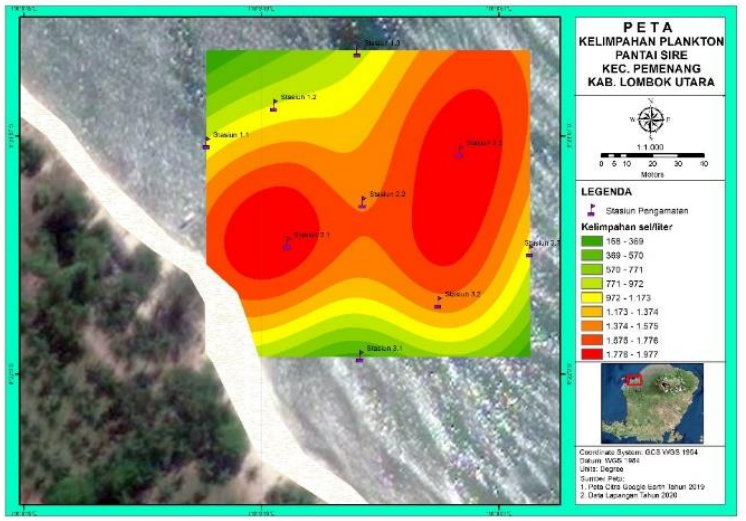

Gambar 2 Peta Sebaran Kelimpahan Plankton di Pantai Sire, Kabupaten Lombok Utara

\section{Indeks Diversitas}

Indeks Shannon-Wienner dilakukan untuk mengetahui tingkat diversitas jenis plankton yang berada di lokasi penelitian. Indeks keanekaragaman pada plankton berkisar antara 1.117505-1.841236 (Gambar 3). Pada indeks ini, terlihat bahwa tingkat keragaman dari jenis fitoplankton berada pada tingkat sedang. Indeks ini menunjukkan adanya keterkaitan dengan kondisi lingkungan perairan (bio-fisika dan kimia). Jika indeks keanekaragaman dibawah 1 menunjukkan komunitas yang tidak stabil, sedangkan indeks keanekaragaman kisaran antara 1-3 menunjukkan stabilitas komunitas yang berada pada tingkat sedang dan indeks keanekaragaman lebih dari 3 menunjukkan stabilitas komunitas plankton pada tingkat stabil (tinggi).

Indeks keseragaman pada fitoplankton berada pada kisaran antara 0.4507180.673373 . Nilai yang didapat menunjukkan bahwa penyebaran jenis plankton di setiap stasiunnya merata. Indeks ini melihat seberapa besar kesamaan penyebaran jumlah individu pada tingkat komunitas (Odum, 1993). Indeks keseragaman yang mendekati 1 menunjukkan keseragaman antar spesies tergolong merata, sedangkan bila mendekati 0 , keseragaman antar spesies tergolong rendah.

Indeks dominansi pada plankton berkisar antara 0.233508-0.522215. Nilai tersebut menunjukkan bahwa tidak ada genus yang dominan dalam perairan tersebut. Hal ini diketahui karena nilai indeks dominansi yang mendekati 0 menunjukkan bahwa tidak ada genus yang dominan. Sebaliknya, jika nilai mendekati 1 menunjukkan adanya genus yang dominan. Kondisi tersebut menunjukkan adanya keadaan yang tidak stabil yang disebabkan oleh adanya tekanan ekologis (Magurran, 1988). 


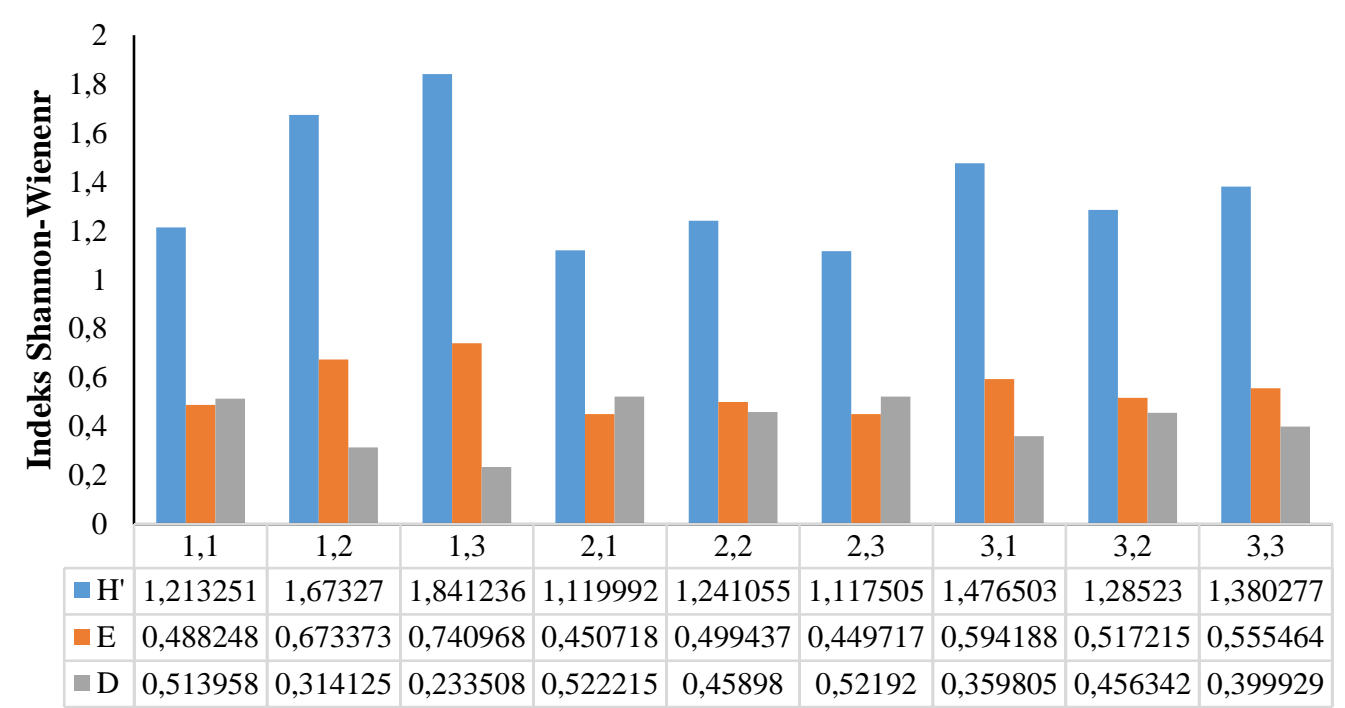

Stasiun

Gambar 3 Indeks Keanekaragaman (H'), Keseragaman (E) dan Dominansi (D)

\section{KESIMPULAN}

Jenis plankton yang ditemukan sebanyak 12 genus fitoplankton yang berasal dari kelompok Bacillariophyta, diantaranya yaitu: Biddulphia, Coscinodiscus, Cocconeis, Cylindrotheca, Diploneis, Fragilaria, Gyrosigma, Licmophora, Navicula, Nitzschia, Pleurosigma, dan Triceratium. Kelimpahan jenis plankton terbanyak ditemukan pada stasiun yang berdekatan dengan daerah lamun yaitu pada Stasiun 2 . Indeks diversitas pada komunitas plankton di sekitar Pantai Sire, Kabupaten Lombok Utara menunjukkan tingkat keragaman, dan keanekaragaman berada pada tingkat sedang/stabil, namun pada indeks dominansi menunjukkan tidak adanya jenis plankton tertentu yang mendominansi.

\section{UCAPAN TERIMA KASIH}

Penulis mengucapkan terimakasih yang sebesar-besarnya kepada Universitas
Mataram yang telah memberikan bantuan sarana dan prasarana yang mendukung terselenggaranya kegiatan penelitian ini, diantaranya fasilitas Laboratorium Kimia Analitik FMIPA dan Laboratorium Bioekologi Perairan Jurusan Perikanan dan Ilmu Kelautan. Terimakasih juga kami sampaikan kepada mahasiswa program studi budidaya perairan yang banyak membantu dalam kegiatan survei dan pengambilan sampel penelitian.

\section{DAFTAR PUSTAKA}

Adinugroho M, Subiyanto, Haeruddin. 2014. Komposisi dan Distribusi Plankton di Perairan Teluk Semarang. Saintifika 16 (2) : 39-48.

Allen WE, CUI'P EE. 1935. Plankton diatoms of Javaseas, Ann.D.Jard.Buitenzord,. 44 (2) : 101174.

APHA. 2005. Standard methods for the examination of water and waste water. American Public Health 
Association, American Water Works Association, and Water Pollution Control Federation. 21th edition. Washington D.C. (US).

Dahuri R. 2003. Keanekaragaman Hayati Laut - Aset Pembangunan Berkelanjutan Indonesia. PT. Gramedia Pustaka Utama, Jakarta.

Davis CC. 1955. The marine and fresh-water plankton. Michigan University Press, Michigan.

Direktorat Kepolisian Perairan NTB. 2017. Data-data Wilayah Pesisir dan Perairan Provinsi NTB. Diambil dari http://ntb.polri.go.id/wpcontent/uploads/2017/02/data-datawilayah-pesisir-dan-perairanprovinsi-ntb.pdf

Hartoko A. 2013. Oceanographic Characters and Plankton Resources of Indonesia. Graha Ilmu, Yogyakarta.

Larasati CE, Kawaroe M, Prartono T. 2015. Karakteristik Diatom di Selat Rupat Riau. Ilmu Kelautan 20 (4) : 223232.

Lebour MV. 1930. The Planktonic Diatoms of the Northern Seas. Ray Society Publications.

Lovadi I, Andriani S, Setyawati TR. 2015. Kelimpahan dan Sebaran Horisontal Fitoplankton di Perairan Muara Sungai Kakap Kabupaten Kubu Raya. Protobiont. 4 (1) : 29-37.

Magurran, AE. 1988. Ecology Diversity and Its Measurement. Princeton University Press, New Jersey.
Mukherjee A, Basu A, Chakraborty S, Das S, De TK. 2013. Salinity Might be the Most Influential Governing Factor of Cell Surface Size of Coscinodiscus in Well Mixed Tropical Estuarine Waters. Int. J. Life Sci Edu Res. 1 (2) : 81-90

Nogueira MG. 2000. Phytoplankton Composition, Dominance and Abundance as Indicators of Environmental

Compartmentalization in Jurumirim Reservoir (Paranapanema River), São Paulo, Brazil. Hydrobiologia. 431 (23) :115-128. doi : 10.1023/A:1003769408757

Nontji A. 2007. Laut Nusantara. Penerbit Djambatan, Jakarta.

Odum EP. 1993. Dasar-Dasar Ekologi (3th). (Terj.). Gajah Mada University Press, Yogyakarta.

Risamasu FJ, Prayitno HB. 2011. Kajian Zat Hara Fosfat, Nitrit, Nitrat dan Silikat di Perairan Kepulauan Matasiri, Kalimantan Selatan. IJMS 16 (3) : 135-142.

Yerli SV, Kıvrak E, Gürbüz H, Manav E, Mangit F, Türkecan O. 2012. Phytoplankton Community, Nutrients and Chlorophyll A in Lake Mogan (Turkey); With Comparison Between Current and Old Data. Turk. J. Fish. Aquat. Sci 12: 95-104. doi: 10.4194/1303-2712-v12_1_ 12 